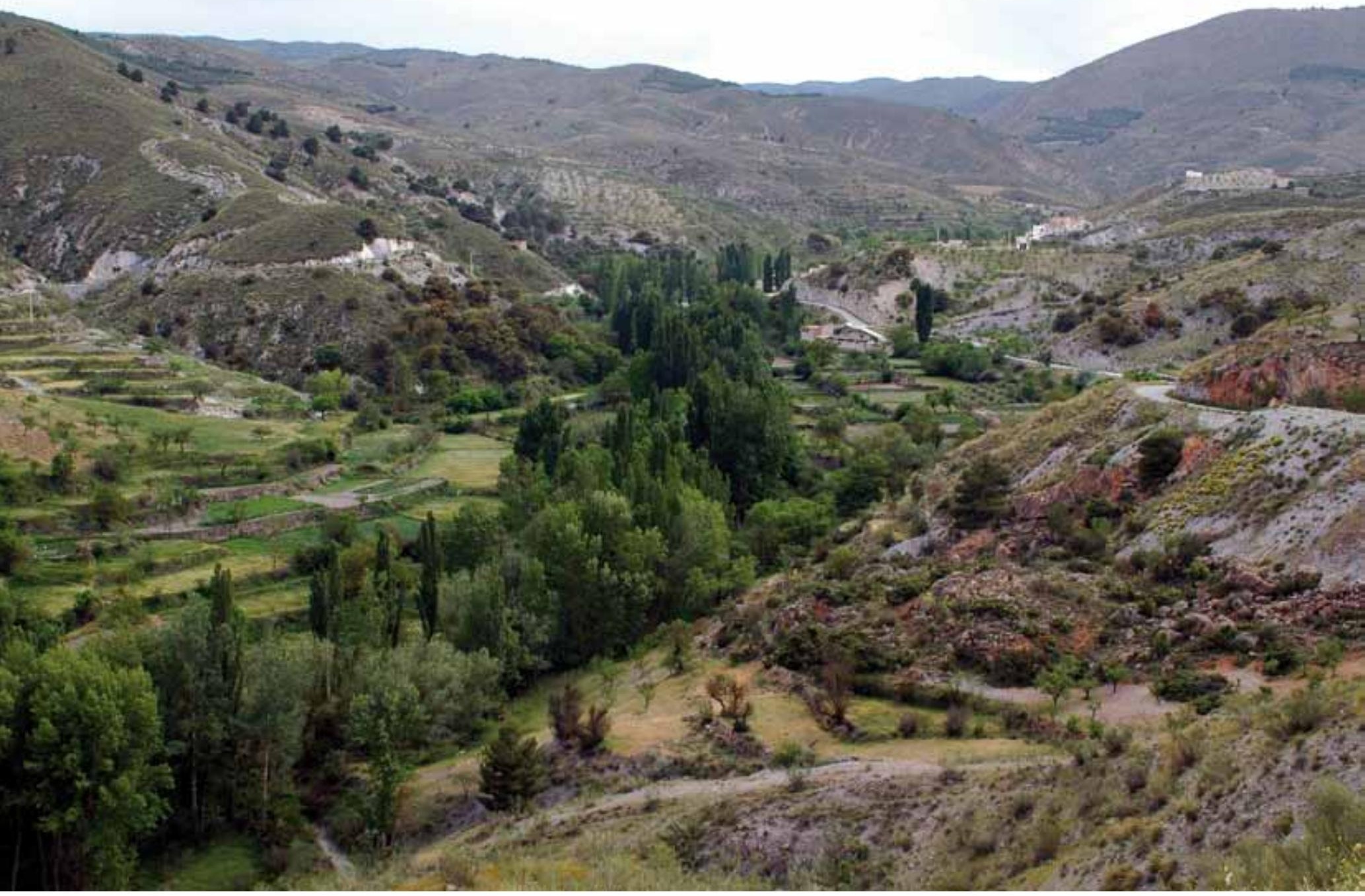

El curso alto del Almanzora se encaja en pequeñas vegas lineales con bosques de galería. Foto: Rodolfo Caparrós Lorenzo (de todas las imágenes de este artículo) 


\section{El valle del Almanzora}

Rodolfo Caparrós Lorenzo, geógrafo y urbanista, consultor de desarrollo territorial
El espacio geográfico almeriense tiene unos rasgos que lo identifican claramente: es un sotavento mediterráneo árido y montañoso. Estos son los datos estructurales de la geografía y el paisaje de Almería, que se presentan de una forma matizada, en función de la altitud, de la orientación de las laderas y de la distancia respecto a la costa. Este espacio geográfico aparece compartimentado por la disposición orográfica, estableciendo ritmos, cuencas y espacios de identidad matizada.

El valle del Almanzora es uno de esos compartimentos. Se extiende en dirección oeste-este, desde la cabecera en el término de Alcóntar, que linda con la provincia de Granada, hasta la desembocadura entre Palomares y Villaricos, en término de Cuevas del Almanzora. El valle aparece enmarcado en su curso alto y medio por las laderas de umbría de la sierra de los Filabres al sur y al norte por los glacis y laderas de solana de las sierras de Lúcar y las Estancias. En el curso bajo, el río se encaja atravesando sierra de Almagro, donde forma el vaso del embalse de Cuevas del Almanzora, tras el cual se dirige directamente al mar. En el fondo del valle, el río Almanzora jerarquiza todos los cauces de la cuenca. Su principal alimentación viene de los cauces afluentes por el sur, por la margen derecha del rio, que provienen de los Filabres. Los del norte son menos numerosos, y de menor aportación de agua, pero ésta puede presentarse de forma muy torrencial, con avenidas de gran caudal.

Un corte transversal del valle nos ofrece una imagen asimétrica, muy caracteristica del modelado del relieve almeriense: las laderas de umbría, más húmedas y forestadas, caen directamente hasta el fondo del valle, mientras que las de solana del norte, sometidas a una intensa erosión, resuelven su contacto con el valle mediante glacis, suaves planos inclinados formados por los sedimentos de esas laderas norteñas. En estos glacis, la red hidrográfica que forman los afluentes de la margen izquierda del Almanzora se encaja y produce una interesante diversidad de geoformas, propias del ámbito sedimentario.

La litología también contiene una gran capacidad explicativa del asentamiento. De las tres esferas litológicas del Almanzora (complejos filábride y alpujárride y materiales sedimentarios), el complejo alpujárride (alternancia de calizas permeables y filitas impermeables, $y$, en consecuencia, numerosos manantiales de ladera) y su contacto con el sedimentario albergan la práctica totalidad de los asentamientos, mientras que el filábride, presente en las zonas altas y compuesto por esquistos paleozoicos impermeables, no permite más aprovechamiento hídrico que el de la escorrentía superficial.

La vegetación refleja la alternancia solana/umbría y las grandes diferencias de altitud en la comarca. Todos los pisos bioclimáticos mediterráneos aparecen representados en la zona, y aunque la cubierta vegetal originaria ha sufrido impactos de diversas fases de explotación humana, todavía conserva una interesante visibilidad, desde el piornal y el matorral almohadillado de las cumbres, hasta el dominio del encinar en media ladera, con ejemplares destacadísimos como la encina de la Peana o la del Marchal del Abogado, llegando hasta el monte bajo mediterráneo, espléndidamente representado en la zona baja del valle. Monumentos naturales como el cerro de la Mata Lobera dan cuenta también del interés ecológico de la zona.

Este valle constituye un ecomuseo del mundo mediterráneo, albergando toda la diversidad climática, geológica y botánica de este mundo. Esta diversidad tiene su origen en la altitud. Desde las altas cumbres de la sierra de los Filabres, nevadas durante la temporada invernal, hasta las tierras bajas de la desembocadura, castigadas por una extrema aridez, el valle del Almanzora presenta un variado gradiente de situaciones físicas.

En este marco físico, y en permanente diálogo con él, se ha producido la ocupación humana en una secuencia histórica tan profunda como cabe esperar de un espacio mediterráneo como éste.

Si la altitud es el dato principal de la diversidad física, el agua y las laderas conforman el relato de la ocupación humana de este espacio, de forma que la posición de los asentamientos en los distintos puntos de la ladera caracterizan los patrones de ocupación de cada época histórica. 


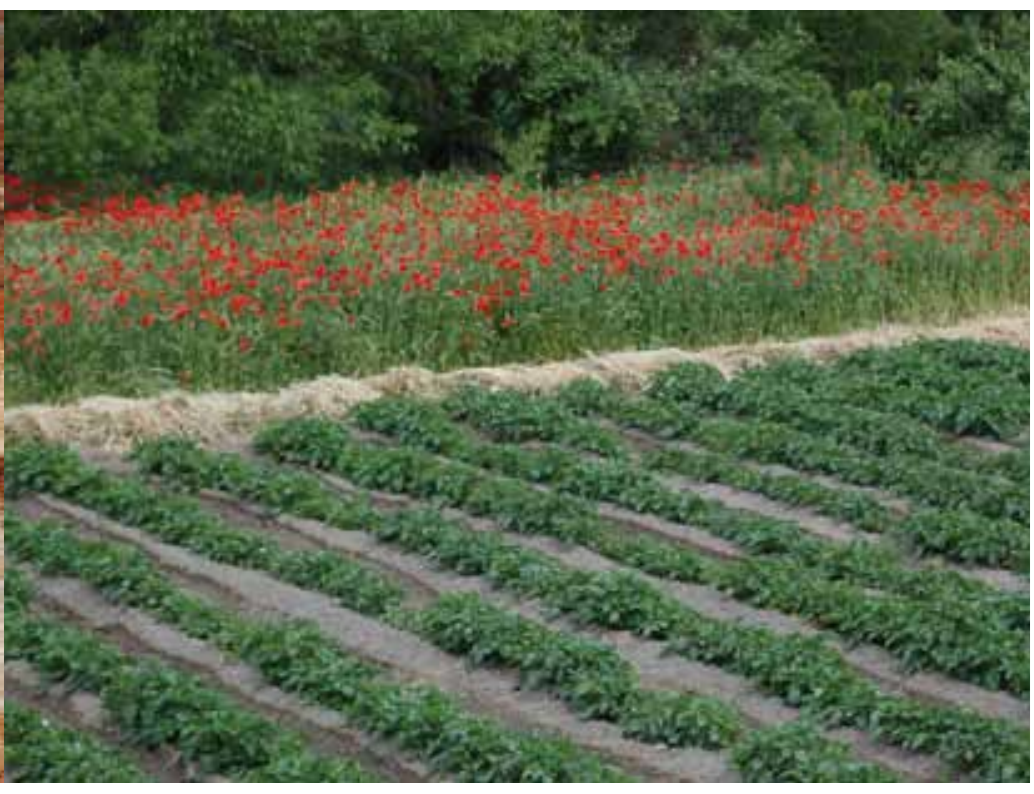

Cultivo de vega en Alcóntar

el duque de Medinaceli con Urrácal y Olula, Cantoria y Partaloa al del Infantado o el marquesado de Almanzora, que acabaría integrándose en el de los Vélez por compra), permaneciendo otra gran parte en realengo. El regadio en vegas, base de la economía hispano-musulmana y morisca, se complementa ahora con los secanos cerealistas y la explotación de pastos y monte.

La explotación minera, históricamente presente con el mármol de Macael, y el talco en la zona de Lúcar-Somontín, se diversifica en la época contemporánea, en torno a los cotos mineros de Bacares y Serón, para cuya explotación del mineral de hierro se desarrollan grandes infraestructuras de transporte (cables aéreos, tendido ferroviario Baza-Almendricos) y poblados de colonización minera, como Las Menas, lo que contribuye a madurar una estructura territorial que, aunque decae desde el cierre minero en la década de los 60 del siglo XX, sienta las bases del nuevo modelo territorial del valle. Este contacto con la modernidad minero-industrial y con los mercados internacionales vino de la mano de compañías inglesas, que explotan tanto las minas como los sistemas de transporte. El ingeniero inglés Gustave Gillman es un personaje que simboliza la época y que nos ha legado una impresionante colección de fotografías, técnica de la que era un pionero.

Tras la crisis minera, la comarca sufre una intensa emigración, que sólo se ve frenada por el auge de las explotaciones de mármol y piedra natural del distrito de Macael. Este proceso migratorio comparte caracteristicas con los fenómenos erosivos. Afecta especialmente al hábitat diseminado y los más pequeños núcleos de población. Se ceba en las laderas y desplaza a la población a través del valle hacia la costa, donde estos "sedimentos" humanos se redistribuyen.

Es el aglomerado de actividades en torno a la extracción de mármol y piedra la base del nuevo sistema productivo local, donde

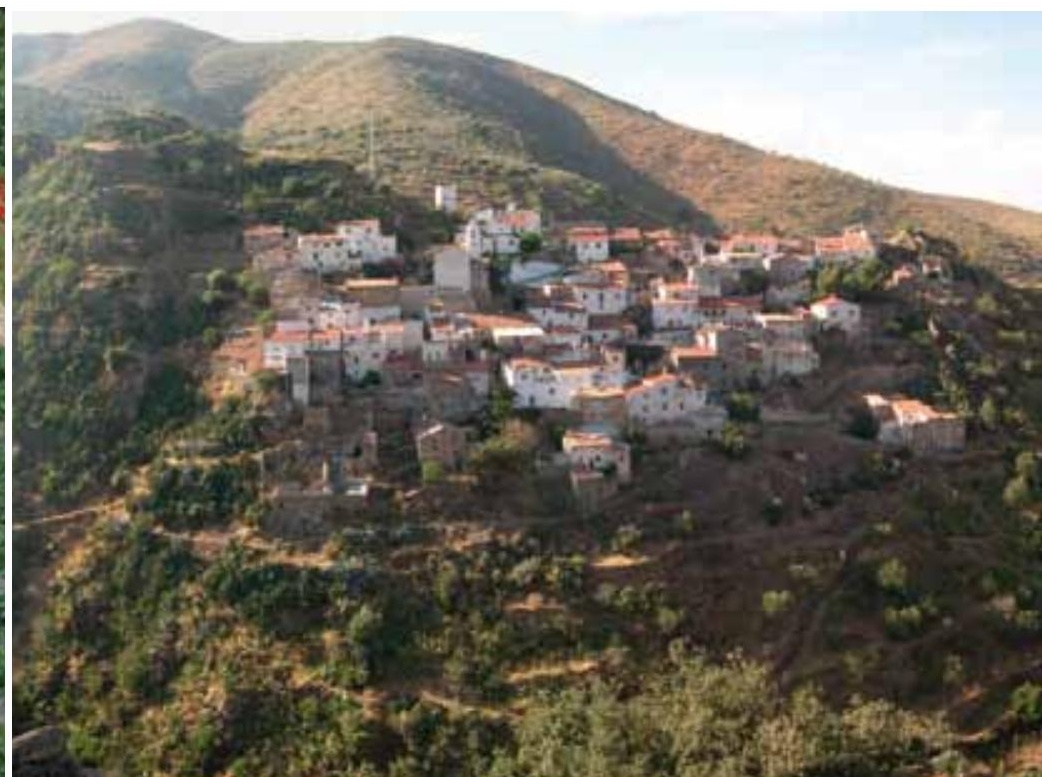

Chercos el Viejo, joya de los asentamientos en ladera

también destacan la producción agroalimentaria de calidad, que hereda el conocimiento y saber hacer del mundo rural (jamón e industrias cárnicas, aceite, vino, esencias), y un potencial turístico que empieza a desvelarse tras las primeras intervenciones públicas, como el Plan Turistico. En el horizonte despuntan elementos esperanzadores: la autovía del Almanzora, en construcción, el parque tecnológico de la Piedra, los parques eólicos, las estrategias de desarrollo rural y turístico, que conviven con problemas cuya superación requiere grandes esfuerzos colectivos (normalización del mercado laboral, reorientación de las demandas de turismo residencial).

La sociedad del valle del Almanzora, heredera de la experiencia cultural a lo largo de la historia, tiene formas de expresión genuinas, de una interesante personalidad. Esta se expresa en la arquitectura popular, en la fiesta, en la gastronomía, en una manera de entender el mundo en la que las raices de una sociedad rural mediterránea conviven con un espiritu emprendedor que garantiza la adaptación a los nuevos retos del mundo global.

Todos estos rasgos señalados, tanto físico-naturales como culturales, comparecen en forma de paisaje, ofreciéndose al disfrute y a la comprensión del significado de este territorio. El paisaje del valle del Almanzora es, de esta manera, uno de sus principales atractivos. Diversidad, visibilidad, gran densidad de información y el extraordinario interés de sus múltiples escalas de percepción, son los elementos característicos del paisaje almanzorí.

En el paisaje, contenedor de la memoria colectiva y de la identidad del sitio, confiamos para el reforzamiento de la motivación y el compromiso ciudadano contemporáneo de sus habitantes, y para que facilite la apertura a un mundo de oportunidades que exige el reconocimiento de la lógica de sus retos propios. 